\title{
Porcine Respiratory Pathogens in Swine Farms Environment in Mexico
}

\author{
Victor M. Loera-Muro1, Abraham Loera-Muro1, Marcela Morfín-Mata², Mario Jacques3, \\ Francisco J. Avelar-Gonzálezi ${ }^{1}$ Flor Ramírez-Castillo', Elsa M. Ramírez-López ${ }^{1}$, \\ Alma L. Guerrero-Barrera ${ }^{4^{*}}$ \\ ${ }^{1}$ Centro de Ciencias Básicas, Universidad Autónoma de Aguascalientes, Aguascalientes, México \\ ${ }^{2}$ Keken, Jefatura Sitio 2 y WTF, Mérida, México \\ ${ }^{3}$ Groupe de Recherche sur la Maladies Infectieuses du Porc, Faculté de Médecine Vétérinaire, Université de \\ Montréal, St-Hyacinthe, Québec, Canada \\ ${ }^{4}$ Laboratorio de Biología Celular y Tisular, Departamento de Morfología, Centro de Ciencias Básicas, \\ Universidad Autónoma de Aguascalientes, Aguascalientes, México \\ Email: ${ }^{*}$ alguerre@correo.uaa.mx
}

Received 25 May 2014; revised 10 July 2014; accepted 23 July 2014

Copyright (C) 2014 by authors and Scientific Research Publishing Inc.

This work is licensed under the Creative Commons Attribution International License (CC BY).

http://creativecommons.org/licenses/by/4.0/

(c) (i) Open Access

\section{Abstract}

Respiratory pathogens are the main health problem in the swine industry worldwide. These pathogens are transmitted by direct contact between animals or by aerosols and however are not well known yet, if the environment works as its reservoir, inoculum and/or dispersion medium. The objective of this study was to determine the presence of respiratory pathogens in environmental samples from swine farms in Aguascalientes, Mexico, through of PCR and RT-PCR techniques. The bacteria Actinobacillus pleuropneumoniae and Pasteurella multocida were found viable in samples from water, food, soil and air. Streptococcus suis was found in a viable state in water samples. Haemophilus parasuis, Porcine Reproductive and Respiratory Syndrome virus and Swine Influenza virus (H1N1 and H3N2) were detected in drinking water samples. Mycoplasma hyopneumoniae and Porcine Circovirus type 2 (PCV2) were not detected in environmental samples. These results suggest that the environment of the farms acts as a reservoir, inoculum and/or vehicle of dispersion for these pathogens except for M. hyopneumoniae and PCV2.

\section{Keywords}

Environment, Respiratory Pathogen, Porcine Respiratory Disease Complex, PCR and RT-PCR

\footnotetext{
${ }^{*}$ Corresponding author.
}

How to cite this paper: Loera-Muro, V.M., Loera-Muro, A., Morfín-Mata, M., Jacques, M., Avelar-González, F.J., RamírezCastillo, F., Ramírez-López, E.M. and Guerrero-Barrera, A.L. (2014) Porcine Respiratory Pathogens in Swine Farms Environment in Mexico. Open Journal of Animal Sciences, 4, 196-205. http://dx.doi.org/10.4236/ojas.2014.44025 


\section{Introduction}

The pig is an animal with intensive production around the world. In this type of production, under normal conditions, the animals are concurrently infected by one or more respiratory viral or bacterial pathogens [1]-[3]. Respiratory diseases in pigs are the main health problem affecting the pork industry today, produce up to $50 \%$ mortality in farms, resulting in great economic losses [4] [5]. Only in United States, Porcine Reproductive and Respiratory Syndrome virus (PRRSV) produces losses of $\$ 560$ million yearly. The losses estimated for Streptococcus suis are around $\$ 300$ million yearly [6]-[8]. Respiratory disease in pigs is common in modern pork production worldwide and is often referred to as porcine respiratory disease complex (PRDC). PRDC is polymicrobial in nature, and results from infection with various combinations of primary and secondary respiratory pathogens [9]. There are a variety of viral and bacterial pathogens commonly associated with PRDC including Actinobacillus pleuropneumoniae, Streptococcus suis, Pasteurella multocida, Haemophilus parasuis, Mycoplasma hyopneumoniae, Porcine Reproductive and Respiratory Syndrome virus (PRRSV), Swine Influenza virus (SIV) and Porcine Circovirus type 2 (PCV2) [9]-[18]. These pathogens are dispersed and infected pigs through direct contact between animals and by aerosols [19]-[21]. There are not many studies that show that the environment in the farm acts as a reservoir or dispersal means for respiratory pathogens [1] [14] [22]. The aim of the present study was therefore, to identify the main porcine respiratory pathogens associated with PRDC: A. pleuropneumoniae, P. multocida, $H$. parasuis, $S$. suis, $M$. hyopneumoniae, PRRSV, SIV and PCV2, in the environment that surrounds pigs in swine farms in Aguascalientes, Mexico.

\section{Materials and Methods}

\subsection{Sampling Environmental Samples}

The environmental and nasal samples were collected from 12 different swine farms located at Aguascalientes, Mexico. A compound sampling scheme was done as described by Cochran [22] [23]. All farms sampled were small farms not technified, with an average of 100 animals, including animals in the process of fattening and breeding females. All animals in these farms had the basic vaccination described by Mexican Standards for Animal Health described by SAGARPA that includes vaccines against Bordetella bronchiseptica, Mycoplasma hyopneumoniae, Actinobacillus pleuropneumoniae from PRDC (SAGARPA: Ministry of Agriculture, Livestock, Rural Development, Fisheries and Food). Likewise, no reports of outbreaks of PRDC in the area exist. Sampling was done from December of 2009 through January 2010. The number of samples obtained per farm was 5 - 10 for farms with 100 - 1000 animals and 11 - 20 for farms with 1000 - 3000 animals. The samples taken were of water, food, soil, air, urine and nasal swab. The total of number of samples is shown in Table 2. Water samples were taken as described Loera-Muro et al. [22]. Food samples were taken directly from top of the feeder. Soil samples were taken directly from the floor on which the animals were with sterile spatula. For the air samples were taken on blood agar (5\% sheep blood) and BHI agar plates (Bioxon, México), both supplement with NAD $\left(15 \mu \mathrm{g} \cdot \mathrm{ml}^{-1}\right)$, for 5 minutes. Urine samples were taken directly from pigs urinating in sterile tubes. Finally, nasal swab samples were taken like described Loera-Muro et al. [15].

\subsection{Sampling Procedure.}

Environmental samples from water, food, soil, urine and nasal swab were plated on blood agar (5\% sheep blood) (Bioxon, México) and BHI agar (Bioxon, México) supplemented with NAD $\left(15 \mu \mathrm{g} \cdot \mathrm{ml}^{-1}\right)$ (Research Organics, Cleveland, $\mathrm{OH})$. Water and urine samples, were directly plated in culture media previously mentioned $(20 \mu \mathrm{l})$. Nasal swab, soil and food consumption samples were homogenized in phosphates buffer saline 1X (PBS1X) sterile and then inoculated $20 \mu \mathrm{l}$ in the mentioned culture media. Air samples were directly incubated. After 24 hours of incubation at $37^{\circ} \mathrm{C}, 5 \% \mathrm{CO}_{2}$, bacterial colonies were harvested and resuspended in $1 \mathrm{ml}$ of lysis buffer (15\% of sucrose, lisozime $0.3 \mathrm{mg} \cdot \mathrm{ml}^{-1}$, EDTA $0.05 \mathrm{M}$ and Tris $1 \mathrm{M}, \mathrm{pH}$ 8) for DNA extraction. DNA isolation was performed as described by Sambrook \& Russell [24] and Loera-Muro et al. [15] modified. Pellets were dried at $37^{\circ} \mathrm{C}$, resuspended in distilled water and kept at $-20^{\circ} \mathrm{C}$ until use for the PCR reactions.

For the pathogenic viruses detection (PRRSV, SIV and PCV 2), the environmental samples were processed directly for the DNA and RNA extraction. Water and urine samples were centrifuged for $10 \mathrm{~min}$ at 10,000 rpm. The supernatant was discarded and the pellet was processed. For food and soil samples, were taken $0.1 \mathrm{~g}$ for processed in $1 \mathrm{ml}$ of lysis buffer. Nasal swab samples were used directly for processed in $1 \mathrm{ml}$ of lysis buffer. 
DNA extraction was made like described above. RNA extraction was done by TRIZOL (Gibco BRL, Canada) as described by the manufacturer. Pellets were resuspended in distilled water and kept at $-20^{\circ} \mathrm{C}$ until use for the PCR reactions.

\subsection{Amplification Protocols}

The detection of respiratory pathogens in this study was performed using PCR, nested PCR and RT-PCR. The strains used in this study and the primer sequences are shown in the Table 1 . All control strains, bacteria and virus, used in this study were from laboratory of Dr. Mario Jacques, GREMIP, Faculty of Veterinary Medicine, Montreal University, Quebec, Canada. Bordetella bronchiseptica was used for make spike controls as described Dousse et al. [25]. Spike control consisted of inoculation of genetic material extracted from the reference strain (1 $\mu \mathrm{M}$ of DNA for reaction) in analyzed samples which resulted was negative and then analyze by PCR. For all samples, including positive controls was used $1 \mu \mathrm{M}$ of DNA or RNA for reaction. Amplicons were analyzed by electrophoresis used 1.5\% agarose gel, and Ethidium bromide stained $\left(1 \mu \mathrm{g} \cdot \mathrm{ml}^{-1}\right)$. Images of the gels were captured using the Chemi Doc (BioRad) image analyzer and the software Quantity One (Bio-Rad, California, USA).

A. pleuropneumoniae nested PCR. PCR against A. pleuropneumoniae was performed as described by Schaller et al. [26] and Loera-Muro et al. [22]. The PCR run conditions were: $95^{\circ} \mathrm{C}$ for 1 min followed by 30 cycles of $94^{\circ} \mathrm{C}$ for $30 \mathrm{~s}, 54^{\circ} \mathrm{C}$ for $30 \mathrm{~s}$ and $72^{\circ} \mathrm{C}$ for 1 min with a final elongation step at $72^{\circ} \mathrm{C}$ for $5 \mathrm{~min}$. PCR was done for ensures one higher sensitivity, which goes to the $10 \mathrm{fg}$.

Toxigenic P. multocida PCR. PCR was done as described Kamp et al. [27]. Run conditions were: 1cycle at $95^{\circ} \mathrm{C}$ for $1 \mathrm{~min}, 32$ cycles at $95^{\circ} \mathrm{C}$ for $30 \mathrm{~s}, 65^{\circ} \mathrm{C}$ for $60 \mathrm{~s}, 72^{\circ} \mathrm{C}$ for $2.5 \mathrm{~min}$ and a final elongation cycle at $72^{\circ} \mathrm{C}$ for $20 \mathrm{~min}$. The limit of detection of this test was up 5 to 10 bacteria ( $25-50 \mathrm{fg}$ ).

Table 1. Reference strain and primer used for PCR.

\begin{tabular}{|c|c|c|c|c|c|c|}
\hline Reference strain & Gene & Gene name & Sequence (5'-3’) & $\mathbf{T m}$ & $\begin{array}{l}\text { Length } \\
\text { (bp) }\end{array}$ & Reference \\
\hline $\begin{array}{c}\text { Actinobacillus } \\
\text { pleuropneumoniae } \\
\text { serotype } 1 \mathrm{~S}-4074\end{array}$ & $\begin{array}{l}\text { apxIVA } \\
\text { apxIVAN }\end{array}$ & $\begin{array}{l}\text { APXIVA-1L } \\
\text { APXIVA-1R } \\
\text { APXIVAN-1L } \\
\text { APXIVAN-1R }\end{array}$ & $\begin{array}{l}\text { TGG CAC TGA CGG TGA TGA T } \\
\text { GGC CAT CGA CTC AAC CAT } \\
\text { GGG GAC GTA ACT CGG TGA TT } \\
\text { GCT CAC CAA CGT TTG CTC }\end{array}$ & $\begin{array}{l}59.5 \\
57.8 \\
59.6 \\
56.2\end{array}$ & 377 & $\begin{array}{l}\text { Schaller et al. } \\
\text { [26]. }\end{array}$ \\
\hline $\begin{array}{l}\text { Pasteurella multocida } \\
\text { serotype } 4 \text { S-4056 } \\
\text { (type D, DNT+) }\end{array}$ & toxA & $\begin{array}{l}\text { TOXA -1F } \\
\text { TOXA-1R }\end{array}$ & $\begin{array}{l}\text { GGT CAG ATG ATG CTA GAT ACT CC } \\
\text { CCA AAC AGG GTT ATA TTC TGG AC }\end{array}$ & $\begin{array}{l}55.5 \\
57.4\end{array}$ & 338 & $\begin{array}{l}\text { Kamp et al. } \\
\quad[27] .\end{array}$ \\
\hline $\begin{array}{c}\text { Streptococcus } \\
\text { suis serotype } 2 \text { (735) }\end{array}$ & $\begin{array}{l}16 S \text { rRNA } \\
\text { cps } 2 J\end{array}$ & $\begin{array}{l}16 S-195 \\
16 S-489 \\
\text { CPS2J-F } \\
\text { CPS2J-R }\end{array}$ & $\begin{array}{c}\text { CAG TAT TTA CCG CAT GGT AGA TAT } \\
\text { GTA AGA TAC CGT CAA GTG AGA A } \\
\text { GTT GAG TCC TTA TAC ACC TGT T } \\
\text { CAG AAA ATT CAT ATT GTC CAC C }\end{array}$ & $\begin{array}{l}55.5 \\
52.3 \\
51.1 \\
54.7\end{array}$ & 459 & $\begin{array}{l}\text { Marois et al. } \\
\quad[28] .\end{array}$ \\
\hline $\begin{array}{l}\text { Haemophilus parasuis } \\
\text { serotype } 5 \text { (Nagasaki) }\end{array}$ & $16 S \operatorname{rRNA}$ & $\begin{array}{l}\text { HPS-F } \\
\text { HPS-R }\end{array}$ & $\begin{array}{l}\text { GTG ATG AGG AAG GGT GGT GT } \\
\text { GGC TTC GTC ACC CTC TGT }\end{array}$ & $\begin{array}{c}58.2 \\
57\end{array}$ & 821 & $\begin{array}{l}\text { Blanco et al. } \\
\text { [29], MacInnes } \\
\text { et al. [30]. }\end{array}$ \\
\hline $\begin{array}{c}\text { Mycoplasma } \\
\text { hyopneumoniae ATCC }\end{array}$ & $16 S$ rRNA & $\begin{array}{l}\text { MH649-F } \\
\text { MH649-R }\end{array}$ & $\begin{array}{l}\text { GAG CCT TCA AGC TTC ACC AGG A } \\
\text { TGT GTT AGT GAC TTT TGC CAC C }\end{array}$ & $\begin{array}{l}63.7 \\
58.6\end{array}$ & 649 & $\begin{array}{l}\text { Cai et al. } \\
\quad[31] \text {. }\end{array}$ \\
\hline $\begin{array}{c}\text { Porcine Reproductive } \\
\text { and Respiratory } \\
\text { Syndrome Virus. }\end{array}$ & Orf7 & $\begin{array}{l}\text { ORF7-R } \\
\text { ORF7-F }\end{array}$ & $\begin{array}{l}\text { ATGGCCAGCCAGTCAATCA } \\
\text { TCGCCCTAATTGAATAGGTG }\end{array}$ & $\begin{array}{c}61 \\
56.2\end{array}$ & 448 & $\begin{array}{l}\text { Larochelle } \\
\text { et al. [33]. }\end{array}$ \\
\hline $\begin{array}{l}\text { Swine Influenza } \\
\text { Virus H3N2, H1N1. }\end{array}$ & H1 & $\begin{array}{l}\text { H1-F } \\
\text { H1-R } \\
\text { H3-F } \\
\text { H3-R } \\
\text { N1-F } \\
\text { N1-R } \\
\text { N2-F } \\
\text { N2R }\end{array}$ & $\begin{array}{c}\text { GGG ACA TGT TAC CCA GGA GAT } \\
\text { GCA TTG TAT GTC CAA ATA TCC A } \\
\text { TAT GCC TGG TTT TCG CTC AA } \\
\text { TTC GGG ATT ACA GTT TGT TG } \\
\text { GGT TCC AAA GGA GAC ATT TTT G } \\
\text { CTA TCC AAA CAC CAT TGC CAT A } \\
\text { TGC GAT CCT GAC AAG TGT TAT C } \\
\text { CAG ACA CAT CTG ACA CCA GGA T }\end{array}$ & $\begin{array}{l}58.5 \\
55.9 \\
60.2 \\
54.7 \\
58.4 \\
58.3 \\
58.6 \\
58.4\end{array}$ & 1006 & $\begin{array}{l}\text { Choi et al. } \\
\text { [34]. }\end{array}$ \\
\hline
\end{tabular}


S. suis all serotypes and serotype 2 multiplex PCR. Multiplex PCR for identification of $S$. suis was done by Marois et al. [28]. The PCR run conditions were: 1 cycle at $95^{\circ} \mathrm{C}$ for $1 \mathrm{~min}, 40$ cycles at $94^{\circ} \mathrm{C}$ for $30 \mathrm{~s}, 60^{\circ} \mathrm{C}$ for $30 \mathrm{~s}, 72^{\circ} \mathrm{C}$ for $1 \mathrm{~min}$ and a final elongation cycle at $72^{\circ} \mathrm{C}$ for $10 \mathrm{~min}$. The sensitivity of this test was $1.4 \mathrm{CFU}$ $\left(280 \mathrm{CFU} \cdot \mathrm{ml}^{-1}\right)$ for serotype 2 and $0.14 \mathrm{CFU}\left(28 \mathrm{CFU} \cdot \mathrm{ml}^{-1}\right)$ for all serotypes.

H. parasuis PCR. To detect the presence of $H$. parasuis, specific primers for the 16s rRNA gene were used [29] [30]. The PCR run conditions were: $95^{\circ} \mathrm{C}$ for 5 min followed by 30 cycles of $94^{\circ} \mathrm{C}$ for $30 \mathrm{~s}, 59^{\circ} \mathrm{C}$ for $30 \mathrm{~s}$ and $72^{\circ} \mathrm{C}$ for 2 min with a final elongation step at $72^{\circ} \mathrm{C}$ for $5 \mathrm{~min}$. The sensitivity of this test was up $69 \mathrm{pg}$ of DNA.

M. hyopneumoniae nested PCR. PCR against M. hyopneumoniae was performed as described by Cai et al. [31]. The PCR run conditions were: 1 cycle at $95^{\circ} \mathrm{C}$ for $1 \mathrm{~min}, 35$ cycles at $94^{\circ} \mathrm{C}$ for $20 \mathrm{~s}, 60^{\circ} \mathrm{C}$ for $30 \mathrm{~s}, 72^{\circ} \mathrm{C}$ for $40 \mathrm{~s}$ and a final elongation cycle at $72^{\circ} \mathrm{C}$ for $7 \mathrm{~min}$. The limit of detection was of $0.18-180,000 \mathrm{CFU} / \mathrm{g}$.

PCV2 PCR. PCR against PCV2 was performed as described by Gagnog et al. [32]. The DNA was amplified by 40 cycles of denaturing at $95^{\circ} \mathrm{C}$ for $40 \mathrm{~s}$, annealing at $55^{\circ} \mathrm{C}$ for $40 \mathrm{~s}$, and extension at $72^{\circ} \mathrm{C}$ for $1 \mathrm{~min}$.

PRRSV and SIV RT-PCR. For these viruses, RT-PCR was performed as Larochelle et al. [33] and Choi et al. [34] respectively. For both viruses, reverse transcription (RT) reaction was performed used One-Step RT-PCR Enzyme Mix (Qiagen, Canada), and $5 \mu$ of RNA. RT conditions were 1 cycle of 30 min at $50^{\circ} \mathrm{C}$ for follow for 1 cycle of $15 \mathrm{~min}$ at $95^{\circ} \mathrm{C}$ for both pathogens. PRRSV amplification was achieved by 35 cycles of denaturing at $95^{\circ} \mathrm{C}$ for $1 \mathrm{~min}$, annealing at $60^{\circ} \mathrm{C}$ for $1 \mathrm{~min}$, and extension at $72^{\circ} \mathrm{C}$ for $1 \mathrm{~min}$. SIV amplification was carried out at 30 cycles of denaturing at $95^{\circ} \mathrm{C}$ for $1 \mathrm{~min}$, annealing at $60^{\circ} \mathrm{C}$ for $30 \mathrm{~s}$ and extension at $72^{\circ} \mathrm{C}$ for $1 \mathrm{~min}$. The PCR was ended with a final extension step at $72^{\circ} \mathrm{C}$ for $10 \mathrm{~min}$.

\section{Results}

A total of 12 swine farms were analyzed for this study obtaining 692 environmental, nasal swab and urine samples (Table 1). In all farms under study, the sampled animals were a range of weight that was from $25 \mathrm{~kg}$ to 120 kg. Prior to the identification of respiratory pathogens from samples of the swine farms, used PCR and RT-PCR, a spike control, positive control and negative control were done. For the positive control, reference strains were used (Table 1 and Figures 1(a)-(f)). The negative control was done under the same conditions of positive control but without DNA or RNA template (Figures 1(a)-(f)). Spike control were performance for avoid negative false results, due to the heterogeneity of content of the samples after extraction of DNA. For the spike controls, all results were positives, discarding false negative interference of the content of the sample. Finally, crossing test was done with specific primer used for each respiratory pathogen against other bacteria or virus used in this work, confirming the primer specificity (data not shown). Primers against the apxIV gene were used for identification of A. pleuropneumoniae, which are species specific [26]. No bacteria used in this study were amplified with apxIV primers. A. pleuropneumoniae was found in samples of drinking water, food, soil, air and nasal swab in a viable state (Figure 1(a) and Table 2). In the case of $P$. multocida, ToxA primers were used, which are exclusive for toxigenic strain [27]. This test not amplified other strains used in this work. P. multocida was detected in all kinds of samples analyzed (drinking water, food, soil, air, nasal swab and urine), and in all cases, was found in a viable state (Figure 1(c) and Table 2). On the other hand, for S. suis was used a multiplex PCR, with the ability to identify all of the 35 serotypes of $S$. suis, as well as, identify the serotype 2 , which is considered like the most virulent [8]. Figure 1(c) and Table 2 show the presence of $S$. suis in samples from drinking water, soil and nasal swab. Only one positive case for serotype 2 was detected from samples of nasal swab. Another analyzed pathogen was $H$. parasuis, which was detected in drinking water and in a viable state, in nasal swab. H. parasuis primers not amplified other bacteria under analysis in this study (Table 2). M. hyopneumoniae was not detected in environmental samples, only was detected in one sample from nasal swab (Table 2). In the case of viral pathogens, the presence of PRRS, SIV and PCV2 were analyzed. The results for PCV2 detection were negative for all DNA samples analyzed (Table 2). PCV2 PCR test did not amplify other viruses (SIV or PRRSV) or bacteria DNA. PRRSV was detected in samples from drinking water and nasal swab (Figure 1(e) and Table 2). As in the case of PCV2, PCR for PRRSV was specific and nonspecific reactions were obtained. Finally, the SIV identification and subtyping was realized with multiplex RT-PCR. This multiplex RT-PCR was usable for subtiyping in H1N1, H1N2 and H3N2. This technique has proven to be specified for this virus and not amplified other viruses or swine respiratory bacterial pathogens. Swine Influenza virus H1N1 and H3N2 were detected in drinking water and nasal swab samples (Figure 1(f) and Table 2). 

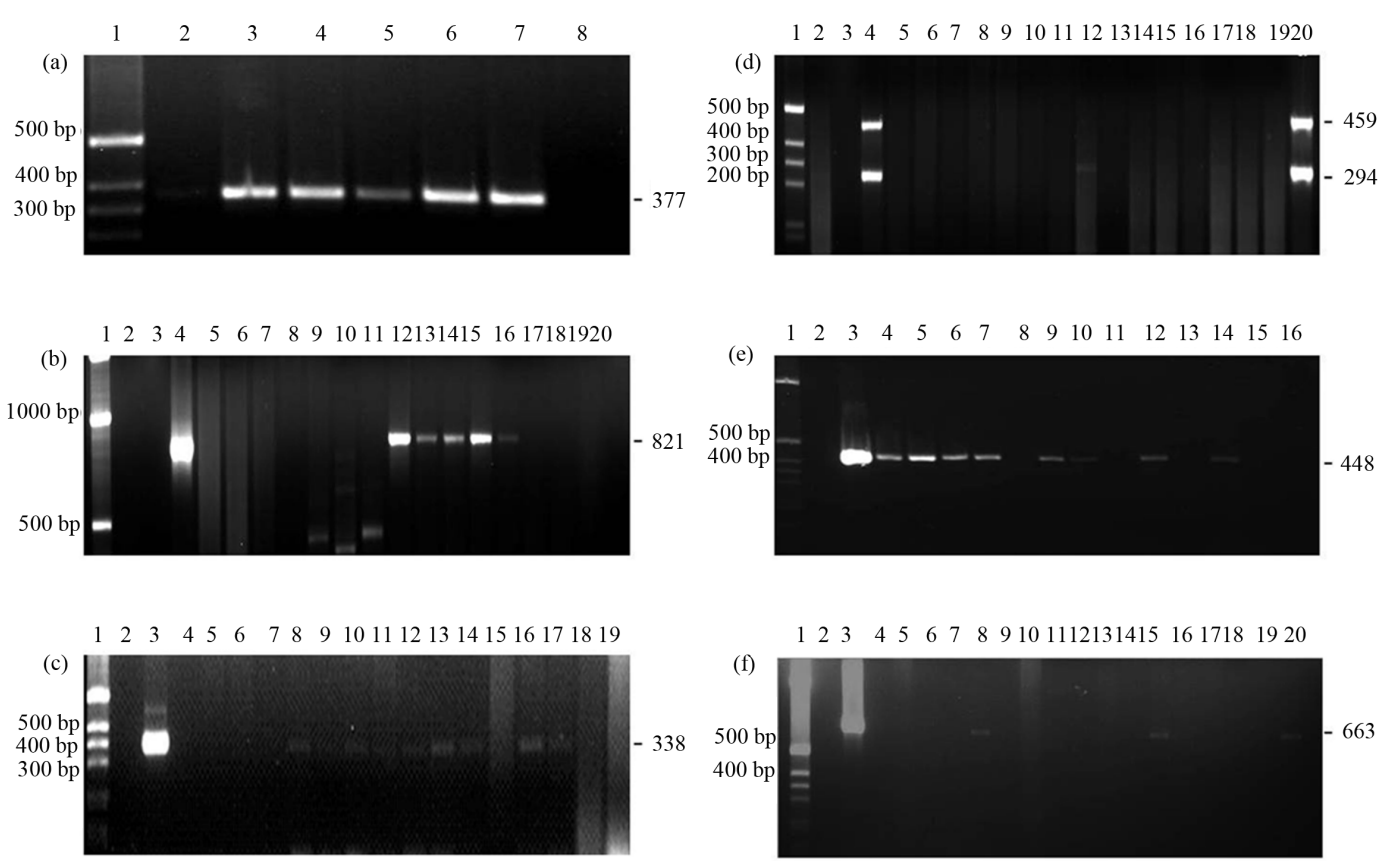

Figure 1. (a) Ethidium bromide stained of Actinobacillus pleuropneumoniae apxIVAN amplicon. Lane 1-1 kbp ladder. Lanes 2 to 6 swine farm environmental samples (drinking water). Lane 7-A. pleuropneumoniae S1 S-4074 (positive control). Lane 8-no template control (negative control); (b) Ethidium bromide stained of Haemophilus parasuis $16 S$ rRNA amplicon. Lane 1-1 kbp ladder. Lane 2-Empty; Lane 3-no template control (negative control) Lane 4-H. parasuis serotype 5 (Nagazaki) (positive control). Lanes 5 to 20 swine farm environmental samples (5 and 6 food samples, 7 to 11 air samples, 12 to 16 nasal samples, 17 and 18 urine samples, 19 and 20 soil samples); (c) Ethidium bromide stained of Pasteurella multocida ToxA amplicon. Lane 1-1 kbp ladder. Lane 2-no template control (negative control). Lane 3-P. multocida serotype 4 S-4056 (type D, DNT+) (positive control). Lane 4 to 19 swine farm environmental samples (4 to 6 and 14 nasal samples, 7 to 9 and 15 soil samples, 10 and 11 air samples, 12 drinking water samples, 16 to 19 food samples); (d) Ethidium bromide stained of Streptococcus suis cps $2 J$ and $16 S$ rRNA amplicon. Lane 1-1 kbp ladder. Lane 2-Empty. Lane 3-no template control (negative control). Lane 4-S. suis serotype 2 (735) (positive control). Lanes 5 to 20 swine farm environmental samples (5 to 8 food samples, 9 to 12 soil samples, 13 to 15 air samples, 16 to 20 drinking water samples); (e) Ethidium bromide stained of PRRSV amplicon. Lane 1-1 kbp ladder. Lane 2-no template control (negative control). Lane 3-PRRSV (American type) (positive control). Lanes 4 to 16-swine farm environmental samples (4, 10, 11 and 14 nasal samples, 5, 7, 9 and 12 drinking water samples, 8, 11 and 13 soil samples, 15 and 16 food samples); (f) Ethidium bromide stained of swine influenza virus $\mathrm{H} 1$ and $\mathrm{H} 3$ amplicon. Lane 1-1 kbp ladder. Lane 2-no template control (negative control). Lane 3-SIV (HIN1 and H3N2) (positive control). Lanes 4 to 20-swine farm environmental samples (5 to 7 and 18 soil samples, 8, 9, 14 and 20 nasal samples, 10, 12, 13 and 17 food samples, 11, 15, 16 and 19 drinking water samples).

Table 2. PCR results per sample. With the exception of the virus samples, another samples come from bacteriological cultures inoculated with environmental samples.

\begin{tabular}{ccccccccc}
\hline Samples & App & Mh & Pm & Ss & Hp & PRRSV & SIV & PCV2 \\
Drinking water & $28 / 130$ & $0 / 11$ & $3 / 10$ & $2 / 26$ & $3 / 24$ & $4 / 4$ & $2 / 9$ & $0 / 11$ \\
Food & $4 / 17$ & $0 / 10$ & $4 / 17$ & $0 / 28$ & $0 / 26$ & $0 / 4$ & $0 / 9$ & $0 / 10$ \\
Soil & $2 / 13$ & $0 / 10$ & $2 / 11$ & $1 / 25$ & $0 / 19$ & $0 / 5$ & $0 / 9$ & $0 / 10$ \\
Air & $17 / 22$ & NS & $5 / 12$ & $0 / 16$ & $0 / 14$ & NS & NS & NS \\
Nasal swab & $8 / 46$ & $1 / 34$ & $7 / 17$ & $3 / 34$ & $6 / 23$ & $4 / 5$ & $2 / 9$ & $0 / 10$ \\
Urine & $0 / 2$ & $0 / 2$ & $2 / 2$ & $0 / 2$ & $0 / 2$ & NS & NS & NS \\
Total & $\mathbf{5 9 / 2 3 0 ~ 2 6 \% ~}$ & $\mathbf{1 / 6 7} \mathbf{1 . 4} \%$ & $\mathbf{2 3 / 6 9} \mathbf{3 3 \%}$ & $\mathbf{6 / 1 3 1} \mathbf{4 . 5 \%}$ & $\mathbf{9 / 1 0 0} \mathbf{9 \%}$ & $\mathbf{8 / 1 8} \mathbf{4 4 \%}$ & $\mathbf{4 / 3 6} \mathbf{1 1 \%}$ & $\mathbf{0 / 4 1 0} \mathbf{0}$
\end{tabular}

App; A. pleuropneumoniae, Pm; P. multocida, Ss; S. suis, Hp; H. parasuis, Mh; M. hyopneumoniae. NS; without samples. 


\section{Discussion}

Respiratory diseases are distributed in all countries where the production of pork is intensively, with prevalence values that can reach up to $100 \%$. In past years, these diseases accounted for the greatest cause of morbidity (of up to $40 \%$ ) and mortality in pigs, with mortality rates of more than $50 \%$ in young pigs and piglets and $60 \%$ in grower/finisher pigs [4] [35]. The main porcine respiratory pathogens were analyzed in this study in environmental samples from drinking water, soil and air. These pathogens are also the most common in the porcine respiratory complex. However, for Mexico, few works have developed about the incidence of these diseases and the type of pathogen causing them. Pathogens of bacterial origin like A. pleuropneumoniae and $P$. multocida were organisms with higher incidence (Table 2). A. pleuropneumoniae, is a specific respiratory pathogen of pigs. A. pleuropneumoniae is the etiologic agent of porcine pleuropneumonia in hyperacute, acute or chronic form [36]-[40]. Positive results based on the apxIV gene amplification indicate the presence of this bacterium in almost all samples, with the exception of urine samples. Williams et al. [41], in the South of Mexico shows the high incidence of A. pleuropneumoniae, to show that around $60 \%$ of the pigs that come to slaughterhouse presented pneumonic injuries, and $51 \%$ of the cases, A. pleuropneumoniae is responsible for it. Positive results obtained here, were not typified. However, other authors report that the most common serotypes in Mexico and North America are the 1, 3, 5, 7 and 12 [30] [41]-[44]. For environmental samples, our group had previously reported the presence of this pathogen in drinking water samples from swine farms where this pathogen could be isolated and observed that these environmental isolates could present biofilm formation as a means of survive outside the pig [22]. On the other hand, $P$. multocida is known as part of the normal flora of the pig, as well as the causal agent of wide variety of infections, usually after primary infections caused by other pathogens or environmental factors [45]-[47]. We identified toxigenic strains in all kind of environmental samples, nasal swab samples and urine samples. The results were based on the ToxA gen amplification, which is found in all toxigenic strains and absent in most of non-toxigenic strains [27] [48] [49]. There are few studies on the relationship of this pathogen in the environment [21]. Likewise, there are few studies on the presence of this pathogen in Mexico. However, our group had reported a high distribution of this pathogen in pig farms in Mexico [15]. Moreover, it is very important to mention that these pathogens were found in a viable state in drinking water, food, air and soil, and in a nasal swab and urine samples. Suggesting that environment of the farms acts as a reservoir, inoculum and/or vehicle of dispersion of these pathogens. Its presence in urine samples has been reported in steers [50] and in people with urinary tract infections [51], but there are no reports about pigs. In the case of $S$. suis, was identified in water, soil and nasal swab samples (Table 2), but the serotype 2, the more pathogens of all of them [10] [52] [53], was only found in one nasal sample. The low incidence of S. suis serotype 2 in our farms could be related with the low incidence of this pathogen in North America [30] [54], and these results are consistent with previous results obtained by our group [15]. Moreover, in the case of the bacteria $H$. parasuis, successfully detected in samples of nasal exudate and water but did not confirm if this was a viable state. However, the percentage of samples found positive for this pathogen from nasal swabs was lower than previously reported in Mexico and in others countries from North America [15] [30]. Similar case is found for $M$. hyopneumoniae, which was detected only in nasal swabs in a low percentage in this study. For this pathogen, previous studies showed much higher levels of presence in pig farms in Mexico, with nearly 20\% [15], and up to $100 \%$ [55]. This difference may be due to the different methodologies used for the collection, processing and detection of this pathogen in the samples, as well as, the differences in the season they were made the same.

Moreover, in the case of the identification of viruses of PRRSV and SIV, common viruses of porcine respiratory complex, was done in nasal exudate and water only. PRRSV was found in the $44 \%$ of tested samples for this virus from water and nasal swab samples. SIV was found in the $11 \%$ of tested samples for this virus from water and nasal swab samples. In the first of the case, there is little information about their presence in Mexico. PRRSV is currently considered to be the most significant and economically important infectious disease to afflict swine worldwide [14] [33] [56] [57]. In the case of samples from water, existing reports that PRRSV can be isolated from water are kept at $25^{\circ} \mathrm{C}-27^{\circ} \mathrm{C}$ for up to 11 days [58], and in swine lagoon effluent kept at $4{ }^{\circ} \mathrm{C}$ for 8 days [59]. Viable virus could also be detected in meat kept at $4^{\circ} \mathrm{C}$ for 7 days and obtained from pigs that had been experimentally infected and euthanized 7 days later [60]. Likewise, PRRS virus can be transmitted by aerosol between farms [21]. Viable virus has been detected in air samples collected $9.1 \mathrm{~km}$ away from their source [61]. In this study, the viability of the virus was not determined, but the detection in water samples is an important factor to be considered. In the case of SIV, Álvarez et al. [55] reported a prevalence of $8.3 \%$ and $65.1 \%$ 
for H1N1 and H3N2 subtypes respectively in Mexico. Influenza A viruses can survive on hard, nonporous surfaces for $12-24 \mathrm{~h}$, and on tissues, cloth and paper for $<8-12 \mathrm{~h}$; transfer of virus from these surfaces to hands can therefore take place up to several hours after initial virus deposition. Transmission of a seasonal H3N2 influenza virus was found to be more efficient by the aerosol route compared with contact with contaminated environmental surfaces (fomites) in the guinea pig model. Despite these studies, the relative contribution from environment in the transmission of influenza viruses in its host remains unknown [62].

All results discussed above are consistent. It is common to find members of the Pasteurellaceae family as well as some Gram-positive bacteria such as S. suis [63], with virus like a PRRSV and SIV, they are common microorganisms in the porcine respiratory complex and the presence of some of them as the PRRSV, facilitates the colonization of the respiratory tract by other pathogens [1] [14]. So, the combination of the respiratory pathogens founded in this study, are most frequently pathogens found in pigs under intensive breeding system [5]. However in relation to the existence of these pathogens in the environment surrounding the animals, few studies exist, so there is no data to compare with these findings. Finally, there are no currently data in Mexico in order to compare the results and thereby determine the dynamics of these pathogens.

\section{Conclusion}

In conclusion, our results have shown that the environment of the farms may serve as a reservoir, inoculum and/or vehicle of dispersion for some of these swine respiratory pathogens. However in relation to the existence of these pathogens in the environment, few studies exist, so it is necessary to continue studies to confirm the relationship between the presence of porcine respiratory pathogens in the environment and the diseases that they cause.

\section{Acknowledgements}

This work was supported by grant FOMIX-AGS-2005-01-15051 to A. L. G.B, from CONACYT, Mexico (No. 258863), and grant from the Natural Sciences and Engineering Research Council of Canada to M. J.

\section{References}

[1] Brockmeier, S., Halbur, P. and Thacker, E. (2003) Porcine Respiratory Disease Complex. In: Brogden, K.A. and Guthmiller, J.M., Eds., Polymicrobial Diseases, ASM Press, Washington DC, 231-258.

[2] Ogawa, H., Taira, O., Hirai, T., Takeuchi, H., Nagao, A., Ishikawa, Y., Tuchiya, K., Nunoya, T. and Ueda, S. (2009) Multiplex PCR and Multiplex RT-PCR for Inclusive Detection of Major Swine DNA and RNA Viruses in Pigs with Multiple Infections. Journal of Virological Methods, 160, 210-214. http://dx.doi.org/10.1016/j.jviromet.2009.05.010

[3] Yue, F., Cui, S., Zhang, C. and Yoon, K. (2009) A multiplex PCR for Rapid and Simultaneous Detection of Porcine Circovirus Type 2, Porcine Parvovirus, Porcine Pseudorabies Virus, and Porcine Reproductive and Respiratory Syndrome Virus in Clinical Specimens. Virus Genes, 38, 392-397. http://dx.doi.org/10.1007/s11262-009-0333-6

[4] Nicholson, T.L., Brockmeier, S.L. and Loving, C.L. (2009) Contribution of Bordetella bronchiseptica Filamentous Hemagglutinin and Pertactin to Respiratory Disease in Swine. Infection and Immunity, 77, 2136-2146. http://dx.doi.org/10.1128/IAI.01379-08

[5] Fablet, C., Marois, C., Kuntz-Simon, G., Rose, N., Dorenlor, V., Eono, F., Eveno, E. and Others Authors (2011) Longitudinal Study of Respiratory Infection Patterns of Breeding Sows in Five Farrow-To-Finish Herds. Veterinary Microbiology, 147, 329-339. http://dx.doi.org/10.1016/j.vetmic.2010.07.005

[6] Hermann, J.R., Hoff, S.J., Yoon, K.J., Burkhardt, A.C., Evans, R.B. and Zimmerman, J.J. (2006) Optimization of a Sampling System for Recovery and Detection of Airborne Porcine Reproductive and Respiratory Syndrome Virus and Swine Influenza Virus. Applied and Environmental Microbiology, 72, 4811-4818. http://dx.doi.org/10.1128/AEM.00472-06

[7] Mondaca-Fernández, E., Murtaugh, M.P. and Morrison, R.B. (2006) Association between Genetic Sequence Homology of Porcine Reproductive and Respiratory Syndrome Virus and Geographic Distance between Pig Sites. Canadian Journal of Veterinary Research, 70, 237-239.

[8] Marois, C., Devendec, L., Gottschalk, M. and Kobisch, M. (2007) Detection and Molecular Typing of Streptococcus suis in Tonsils from Live Pigs in France. Canadian Journal of Veterinary Research, 71, 14-22.

[9] Opriessnig, T., Giménez-Lirola, L.G. and Halbur, P.G. (2011) Polymicrobial Respiratory Disease in Pigs. Animal Health Research Reviews, 12, 133-148. http://dx.doi.org/10.1017/S1466252311000120 
[10] Fittipaldi, N., Segura, M., Grenier, D. and Gottschalk, M. (2012) Virulence Factors Involved in the Pathogenesis of the Infection Caused by the Swine Pathogen and Zoonotic Agent Streptococcus suis. Future Microbiology, 7, 259-279. http://dx.doi.org/10.2217/fmb.11.149

[11] Hansen, M.S., Hjulsager, C.K., Bille-Hansen, V., Haugegaard, S., Dupont, K., Hogedal, P., Kunstmann, L. and Larsen, L.E. (2012) Selection of Method Is Crucial for the Diagnosis of Porcine Circovirus Type 2 Associated Reproductive Failures. Veterinary Microbiology, 144, 203-209. http://dx.doi.org/10.1016/j.vetmic.2009.12.038

[12] Vranckx, K., Maes, D., Marchioro, S., Villarreal, I., Chiers, K., Pasmans, F. and Haesebrouck, F. (2012) Vaccination Reduces Macrophage Infiltration in Bronchus-Associated Lymphoid Tissue in Pigs Infected with a Highly Virulent Mycoplasma hyopneumoniae Strain. BMC Veterinary Research, 8, 24. http://dx.doi.org/10.1186/1746-6148-8-24

[13] Wilkie, W., Harper, M., Boyce, J. and Adler, D. (2012) Pasteurella multocida: Diseases and Pathogenesis. Current Topics in Microbiology and Immunology, 361, 1-22. http://dx.doi.org/10.1007/82_2012_216

[14] Zhao, Z., Qin, Y., Lai, Z., Peng, L., Cai, X., Wang, L., Guo. X. and Yang, H. (2012) Microbial Ecology of Swine Farms and PRRS Vaccine Vaccination Strategies. Veterinary Microbiology, 155, 247-256. http://dx.doi.org/10.1016/j.vetmic.2011.09.028

[15] Loera-Muro, A., Avelar-González, F., Loera-Muro, V., Jacques, M. and Guerrero, A. (2013) Presence of Actinobacillus pleuropneumoniae, Streptococcus suis, Pasteurella multocida, Bordetella bronchiseptica, Haemophilus parasuis and Mycoplasma hyopneumoniae in Upper Respiratory Tract of Swine in Farms from Aguascalientes, Mexico. Open Journal of Animal Sciences, 3, 132-137. http://dx.doi.org/10.4236/ojas.2013.32020

[16] Segalés, J., Kekarainen, T. and Cortey, M. (2013) The Natural History of Porcine Circovirus Type 2: From an Inoffensive Virus to a Devastating Swine Disease? Veterinary Microbiology, 165, 13-20. http://dx.doi.org/10.1016/j.vetmic.2012.12.033

[17] Van Reeth, K. and Ma, W. (2013) Swine Influenza Virus Vaccines: To Change or Not to Change-That's the Question. Current Topics in Microbiology and Immunology, 370, 173-200. http://dx.doi.org/10.1007/82_2012_266

[18] Zhao, M., Liu, X.D., Li, X.Y., Chen, H.B., Jin, H., Zhou, R., Zhu, M.J. and Zhao, S.H. (2013) Systems Infection Biology: A Compartmentalized Immune Network of Pig Spleen Challenged with Haemophilus parasuis. BMC Genomics, 14, 46. http://dx.doi.org/10.1186/1471-2164-14-46

[19] Hermann, J., Hoff, S., Muñoz-Zanzi, C., Yoon, K, Roof, M., Burkhardt, A. and Zimmerman, J. (2007) Effect of Temperature and Relative Humidity on the Stability of Infectious Porcine Reproductive and Respiratory Syndrome Virus in Aerosols. Veterinary Research, 38, 81-93. http://dx.doi.org/10.1051/vetres:2006044

[20] Hermann, J.R., Brockmeier, S.L., Yoon, K.J. and Zimmerman, J.J. (2008) Detection of Respiratory Pathogens in Air Samples from Acutely Infected Pigs. Canadian Journal of Veterinary Research, 72, 367-370.

[21] Desrosiers, R. (2011) Transmission of Swine Pathogens: Different Means, Different Needs. Animal Health Research Reviews, 12, 1-13. http://dx.doi.org/10.1017/S1466252310000204

[22] Loera-Muro, V., Jacques, M., Tremblay, Y., Avelar-González, F., Loera-Muro, A., Ramírez-López, E., MedinaFigueroa, A., González-Reynaga, H. and Guerrero-Barrera, A. (2013) Detection of Actinobacillus pleuropneumoniae in Drinking Water from Pig Farms. Microbiology, 159, 536-544. http://dx.doi.org/10.1099/mic.0.057992-0

[23] Cochran, W.G. (1977) Sampling Techniques. 3rd Edition, Willey and Sons, New York.

[24] Sambrook, J. and Rusell, D.W. (2001) Molecular Cloning, a Laboratory Manual. 3rd Edition, CSHL Press, Cold Spring Harbor, A8.9-A8.16.

[25] Dousse. F., Thomann, A., Brodard, I., Korczak, B.M., Schlatter, Y., Kuhnert, P., Miserez, R. and Frey, J. (2008) Routine Phenotypic Identification of Bacterial Species of the Family Pasteurellaceae Isolated from Animals. Journal of Veterinary Diagnostic Investigation, 20, 716-724. http://dx.doi.org/10.1177/104063870802000602

[26] Schaller, A., Djordjevic, S.P., Eamens, G.J., Forbes, W.A., Kuhn, R., Kuhnert, P., Gottschalk, M., Nicolet, J. and Frey, J. (2001) Identification and Detection of Actinobacillus pleuropneumoniae by PCR Based on the Gene apxIVA. Veterinary Microbiology, 2, 47-62. Microbiology, 2, 47-62. http://dx.doi.org/10.1016/S0378-1135(00)00345-X

[27] Kamp, E.M., Bokken, C.A.M., Vermeulen, M.M., de Jong, M.F., Buys, E.C.M., Reek, F.H. and Smits, M.A. (1996) A Specific and Sensitive PCR Assay Suitable for Large-Scale Detection of Toxigenic Pasteurella multocida in Nasal and Tonsillar Swabs Specimens of Pigs. Journal of Veterinary Diagnostic Investigation, 8, 204-309. http://dx.doi.org/10.1177/104063879600800305

[28] Marois, C., Bougeard, S., Gottschalk, M. and Kobisch, M. (2004) Multiplex PCR Assay for Detection of Streptococcus suis Species and Serotypes 2 and 1/2 in Tonsils of Live and Dead Pigs. Journal of Clinical Microbiology, 42, 31693175. http://dx.doi.org/10.1128/JCM.42.7.3169-3175.2004

[29] Blanco, I., Canals, A., Evans, G., Mellencamp, M.A., Cia, C., Deeb, N., Wang, L. and Galina-Pantoja, L. (2008) Differences in Susceptibility to Haemophilus parasuis Infection in Pigs. Canadian Journal of Veterinary Research, 72, 
228-235.

[30] MacInnes, J.I., Gottschalk, M., Lone, A.G., Metcalf, D.S., Ojha, S., Rosendal, T., Whatson, S.B. and Friendship, R.M. (2008) Prevalence of Actinobacillus pleuropneumoniae, Actinobacillus suis, Haemophilus parasuis, Pasteurella multocida and Streptococcus suis, in Representative Ontario Swine Herds. Canadian Journal of Veterinary Research, 72, 242-248.

[31] Cai, H.Y., Van Dreumel, T., McEwen, B., Hornby, G., Bell-Rogers, P., McRaild, P., Josephson, G. and Maxie, G. (2007) Application and Field Validation of a PCR Assay for the Detection of Mycoplasma hyopneumoniae from Swine Lung Tissue Samples. Journal of Veterinary Diagnostic Investigation, 19, 91-95. http://dx.doi.org/10.1177/104063870701900115

[32] Gagnon, C.A., Music, N., Fontaine, G., Tremblay, D. and Harel, J. (2010) Emergence of a New Type of Porcine Circovirus in Swine (PCV): A Type 1 and Type 2 PCV Recombinant. Veterinary Microbiology, 144, 18-23. http://dx.doi.org/10.1016/j.vetmic.2009.09.072

[33] Larochelle, R., D’Allaire, S. and Magar, R. (2003) Molecular Epidemiology of Porcine Reproductive and Respiratory Syndrome Virus (PRRSV) in Québec. Virus Research, 96, 3-14. http://dx.doi.org/10.1016/S0168-1702(03)00168-0

[34] Choi, Y.K., Goyal, S.M., Kang, S.W., Farnham, M.W. and Joo, H.S. (2002) Detection and Subtyping of Swine Influenza H1N1, H1N2 and H3N2 Viruses in Clinical Samples Using Two Multiplex RT-PCR Assays. Journal of Virological Methods, 102, 53-59. http://dx.doi.org/10.1016/S0166-0934(01)00442-6

[35] Hansen, M.S., Pors, S.E., Jensen, H.E., Bille-Hansen, V., Bisgaard, M., Flachs, E.M. and Nielsen, O.L. (2010) An Investigation of the Pathology and Pathogens Associated with Porcine Respiratory Disease Complex in Denmark. Journal of Comparative Pathology, 143, 120-131. http://dx.doi.org/10.1016/j.jcpa.2010.01.012

[36] Deslandes, V., Denicourt, M., Girard, C., Harel, J., Nash, J.H.E. and Jacques, M. (2010) Transcriptional Profiling of Actinobacillus pleuropneumoniae during the Acute Phase of a Natural Infection in Pigs. BMC Genomics, 11, 98. http://dx.doi.org/10.1186/1471-2164-11-98

[37] Ito, H. (2010) Development of a cps-Based Multiplex PCR for Typing of Actinobacillus pleuropneumoniae Serotypes 1, 2 and 5. The Journal of Veterinary Medical Science, 72, 653-655. http://dx.doi.org/10.1292/jvms.09-0529

[38] Jirawattanapong, P., Stockhofe-Zurwieden, N., Van-Leengoed, L., Wisselink, H., Raymakers, R., Cruijsen, T., Van der Peet-Schwering, C., Nielenb, M. and van Nes, A. (2010) Pleuritis in Slaughter Pigs: Relations between Lung Lesions and Bacteriology in 10 Herds with High Pleuritis. Research in Veterinary Science, 88, 11-15.

http://dx.doi.org/10.1016/j.rvsc.2009.06.007

[39] Li, J.X., Jiang, P., Wang, Y., Li, Y.F., Chen, W., Wang, X.W. and Li, P. (2009) Genotyping of Haemophilus parasuis from Diseased Pigs in China and Prevalence of Two Coexisting Virus Pathogens. Preventive Veterinary Medicine, 91, 274-279. http://dx.doi.org/10.1016/j.prevetmed.2009.06.004

[40] Kim, J.M., Park, S.M., Kim, J.A., Park, J.A., Yi, M.H., Kim, N.S., Bae, J.L., Park, S.G., Jang, Y.S., Yang, M.S. and Kim, D.H. (2011) Functional Pentameric Formation via Coexpression of the Escherichia coli Heat-Labile Enterotoxin B Subunit and Its Fusion Protein Subunit with a Neutralizing Epitope of ApxIIA Exotoxin Improves the Mucosal Immunogenicity and Protection against Challenge by Actinobacillus pleuropneumoniae. Clinical and Vaccine Immunology, 18, 2168-2177. http://dx.doi.org/10.1128/CVI.05230-11

[41] Williams, J.J., Torres-León, M., Echeverria-Coello, P. and Matos-Medina, M. (2000) Aislamiento e identificación de Actinobacillus pleuropneumoniae en pulmones de cerdos con pleuroneumonía crónica sacrificados en el rastro municipal de Mérida, Yucatán, México. Revista Biomédica, 11, 175-181.

[42] Hennessy, K.J., Iandolo, J.J. and Fenwick, B.W. (1993) Serotype Identification of Actinobacillus pleuropneumoniae by Arbitrarily Primed Polymerase Chain Reaction. Journal of Clinical Microbiology, 31, 1155-1159.

[43] Auger, E., Deslandes, V., Ramjeet, M., Contreras, I., Nash, J.H.E., Harel, J., Gottschalk, M., Olivier, M. and Jacques, M. (2009) Host-Pathogen Interactions of Actinobacillus pleuropneumoniae with Porcine Lung and Tracheal Epithelial Cells. Infection and Immunity, 77, 1426-1441. http://dx.doi.org/10.1128/IAI.00297-08

[44] Grasteau, A., Tremblay, Y.D.N., Labrie, J. and Jacques, M. (2011) Novel Genes Associated with Biofilm Formation of Actinobacillus pleuropneumoniae. Veterinary Microbiology, 153, 134-143. http://dx.doi.org/10.1016/j.vetmic.2011.03.029

[45] Kalorey, D.R., Yuvaraj, S., Vanjari, S.S., Gunjal, P.S., Dhanawade, N.B., Barbuddhe, S.B. and Bhandarkar, A.G. (2008) PCR Analysis of Pasteurella multocida Isolates from an Outbreak of Pasteurellosis in Indian Pigs. Comparative Immunology, Microbiology and Infectious Diseases, 31, 459-465. http://dx.doi.org/10.1016/j.cimid.2007.06.003

[46] Bethe, A., Wieler, L.H., Selbitz, H.J. and Ewers, C. (2009) Genetic Diversity of Porcine Pasteurella multocida Strains from the Respiratory Tract of Healthy and Diseased Swine. Veterinary Microbiology, 139, 97-105. http://dx.doi.org/10.1016/j.vetmic.2009.04.027

[47] Hatfaludi, T., Al-Hasani, K., Boyce, J.D. and Adler, B. (2010) Outer Membrane Proteins of Pasteurella multocida. 
Veterinary Microbiology, 144, 1-17. http://dx.doi.org/10.1016/j.vetmic.2010.01.027

[48] Hsuan, S.L., Liao, C.M., Huang, C., Winton, J.R., Chen, Z.W., Lee, W.C., Liao, J.W., et al. (2009) Efficacy of a Novel Pasteurella multocida Vaccine against Progressive Atrophic Rhinitis of Swine. Vaccine, 27, 2923-2929. http://dx.doi.org/10.1016/j.vaccine.2009.03.005

[49] Tang, X.B., Zhao, Z.Q., Hu, J.Y., Wu, B., Cai, X.W., He, Q.G. and Chen, H.C. (2009) Isolation, Antimicrobial Resistance, and Virulence Genes of Pasteurella multocida Strains from Swine in China. Journal of Clinical Microbiology, 47, 951-958. http://dx.doi.org/10.1128/JCM.02029-08

[50] Stalheim, O. and Heddleston, K. (1970) Isolation of Pasteurella multocida from the Urine of Steers. Veterinary Record, 87, 135-136.

[51] Warren, J. and Smith, J. (1984) Pasteurella multocida Urinary Tract Infection. Archives of Pathology \& Laboratory Medicine, 108, 401-402.

[52] Meng, X.P., Shi, Y.B., Ji, W.H., Meng, X.L., Zhang, J., Wang, H.G., Lu, C.P., Sun, J.H. and Yan, Y.X. (2011) Application of a Bacteriophage Lysin to Disrupt Biofilms Formed by the Animal Pathogen Streptococcus suis. Applied and Environmental Microbiology, 77, 8272-8279. http://dx.doi.org/10.1128/AEM.05151-11

[53] Wang, Y., Zhang, W., Wu, Z.F. and Lu, C.P. (2011) Reduced Virulence Is an Important Characteristic of Biofilm Infection of Streptococcus suis. FEMS Microbiology Letters, 316, 36-43. http://dx.doi.org/10.1111/j.1574-6968.2010.02189.x

[54] Bonifait, L., Gottschalk, M. and Grenier, D. (2010) Cell Surface Characteristics of Nontypeable Isolates of Streptococcus suis. FEMS Microbiology Letters, 311, 160-166. http://dx.doi.org/10.1111/j.1574-6968.2010.02086.x

[55] Álvarez, M., Rodríguez, J., Ciprián, A., Rodríguez, L., Ayora, G. and Segura, J. (2004) Serological Profile of Porcine Influenza Virus, Mycoplasma hyopneumoniae and Actinobacillus pleuropneumoniae, in Farms of Yucatán, México. Veterinaria México, 35, 296-305.

[56] Zhou, S.H., Cui, S.J., Chen, C.M., Zhang, F.C., Li, J., Zhou, S. and Oh, J.S. (2009) Development and Validation of an Immunogold Chromatographic Test for On-Farm Detection of PRRSV. Journal of Virological Methods, 160, 178-184. http://dx.doi.org/10.1016/i.jviromet.2009.04.034

[57] Fablet, C., Marois, C., Dorenlor, V., Eono, F., Eveno, E., Jolly, J.P., Le Devendec, L., Kobisch, M., Madec, F. and Rose, N. (2012) Bacterial Pathogens Associated with Lung Lesions in Slaughter Pigs from 125 Herds. Research in Veterinary Science, 93, 627-630. http://dx.doi.org/10.1016/j.rvsc.2011.11.002

[58] Pirtle, E. and Beran, G.W. (1996) Stability of Porcine Reproductive and Respiratory Syndrome Virus in the Presence of Fomites Commonly Found on Farms. Journal of the American Veterinary Medical Association, 208, 390-392.

[59] Dee, S.A., Martinez, B.C. and Clanton, C.J. (2005) Survival of and Infectivity of Porcine Reproductive and Respiratory Syndrome Virus in Swine Lagoon Effluent. The Veterinary Record, 156, 56-57.

[60] Cano, J.P., Murtaugh, M.P. and Dee, S.A. (2007) Evaluation of the Survival of Porcine Reproductive and Respiratory Syndrome Virus in Non Processed Pig Meat. The Veterinary Record, 160, 907-908. http://dx.doi.org/10.1136/vr.160.26.907

[61] Otake, S., Dee, S., Corzo, C., Oliveira, S. and Deen, J. (2010) Long Distance Airborne Transport of Infectious PRRSV and Mycoplasma hyopneumoniae from a Swine Population Infected with Multiple Viral Variants. Veterinary Microbiology, 145, 198-208. http://dx.doi.org/10.1016/j.vetmic.2010.03.028

[62] Belser, J.A., Maines, T., Tumpey, T. and Katz, J. (2010) Influenza A Virus Transmission: Contributing Factors and Clinical Implications. Expert Reviews in Molecular Medicine, 12, Article ID: e39. http://dx.doi.org/10.1017/S1462399410001705

[63] Baele, M., Chiers, K., Devriese, L.A., Smith, H.E., Wisselink, H.J., Vaneechoutte, M. and Haesebrouck, F. (2001) The Gram-Positive Tonsillar and Nasal Flora of Piglets before and after Weaning. Journal of Applied Microbiology, 91, 997-1003. http://dx.doi.org/10.1046/j.1365-2672.2001.01463.x 
Scientific Research Publishing (SCIRP) is one of the largest Open Access journal publishers. It is currently publishing more than 200 open access, online, peer-reviewed journals covering a wide range of academic disciplines. SCIRP serves the worldwide academic communities and contributes to the progress and application of science with its publication.

Other selected journals from SCIRP are listed as below. Submit your manuscript to us via either submit@scirp.org or Online Submission Portal.
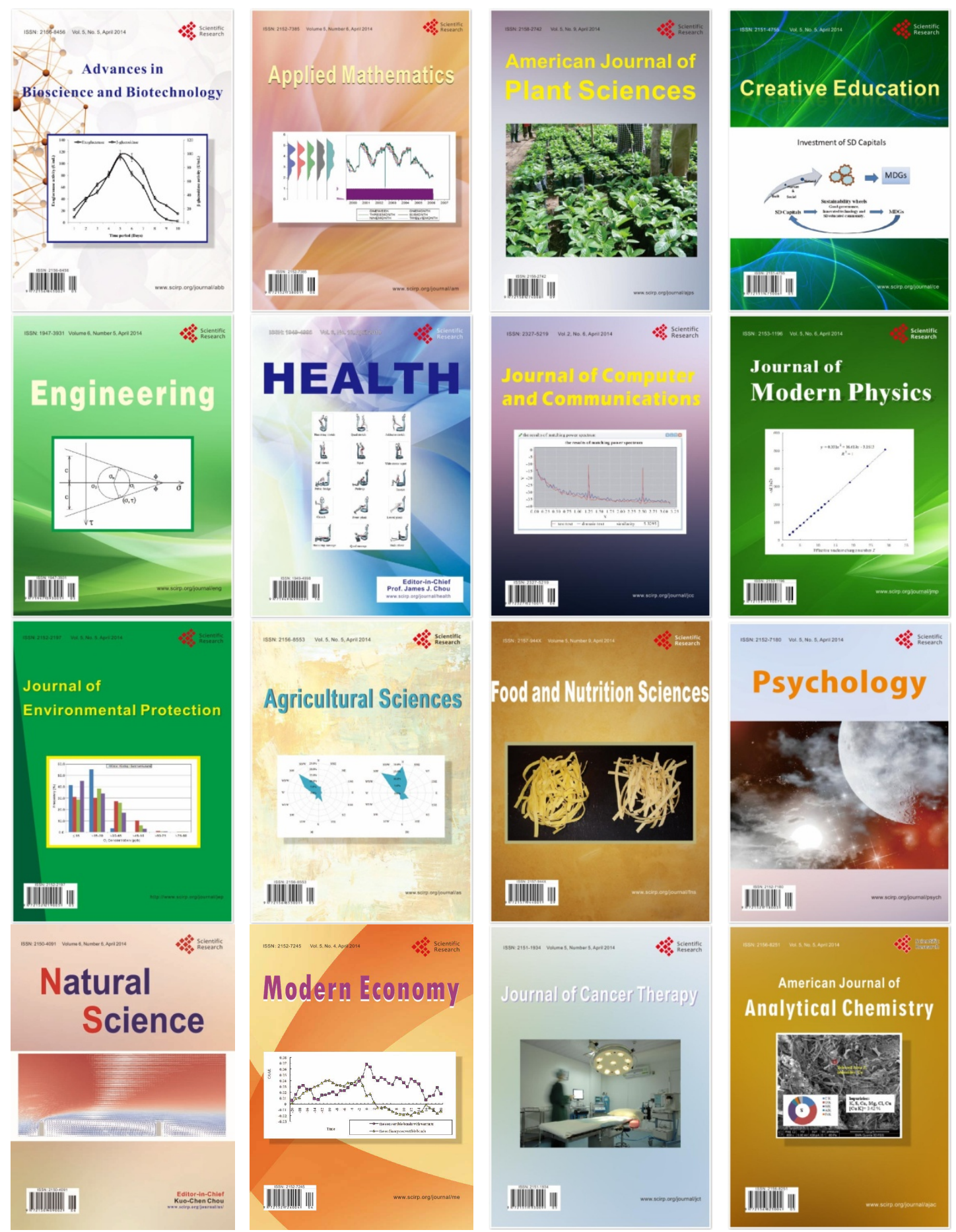